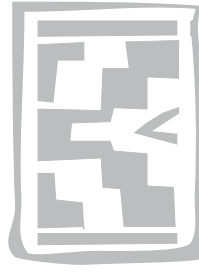

\title{
Influence of dipping practices on the seroprevalence of babesiosis and anaplasmosis in the foot-and-mouth disease buffer zone adjoining the Kruger National Park in South Africa
}

\author{
K.B. STEVENS ${ }^{1 *}$, A.M. SPICKETT ${ }^{2}$, W. VOSLOO ${ }^{2,5}$, D.U. PFEIFFER ${ }^{1}$, E. DYASON ${ }^{3}$ \\ and B. DU PLESSIS 4
}

\begin{abstract}
STEVENS, K.B., SPICKETT, A.M., VOSLOO, W., PFEIFFER, D.U., DYASON, E. \& DU PLESSIS, B. 2007. Influence of dipping practices on the seroprevalence of babesiosis and anaplasmosis in the foot-and-mouth disease buffer zone adjoining the Kruger National Park in South Africa. Onderstepoort Journal of Veterinary Research, 74:87-95

A serological survey of bovine babesiosis and anaplasmosis was conducted in the foot-and-mouth disease buffer zone surrounding the Kruger National Park in South Africa between 2001 and 2003 to determine whether the withdrawal of government-subsidized dipping in certain regions had affected the seroprevalence of these tick-borne diseases. Seroprevalence of Anaplasma marginale and Babesia bovis increased during the study period. This increase was greater in Limpopo Province where farmers had to supply their own acaricide than in Mpumalanga Province where dipping materials were provided by the local Veterinary Services. The number of animals testing positive for $B$. bigemina decreased in both provinces during the study period, which was attributed to possible vector displacement rather than more effective tick control measures. Responses to a questionnaire on ticks and tick-borne diseases revealed local knowledge on the subject to be highly variable and sometimes incorrect.
\end{abstract}

Keywords: Bovine anaplasmosis, bovine babesiosis, dipping practices, FMD buffer zone, Kruger National Park, seroprevalence, South Africa

\section{INTRODUCTION}

South Africa has been accorded a foot-and-mouth (FMD) disease-free without vaccination status by

* Author to whom correspondence is to be directed. E-mail: kstevens@rvc.ac.uk

1 Royal Veterinary College, Hawkshead Lane, North Mymms, Hatfield, AL9 7TA, United Kingdom

2 Onderstepoort Veterinary Institute, Private Bag X05, Onderstepoort, 0110 South Africa

3 Department of Agriculture, Private Bag X 9487, Polokwane, 0700 South Africa

4 CSIR, Private Bag X 11309, Nelspruit, Mbombela, Mpumalanga, 1200 South Africa

5 Department of Veterinary Tropical Diseases, Faculty of Veterinary Science, University of Pretoria, Pretoria, 0002 South Africa

Accepted for publication 11 October 2006-Editor the World Organisation for Animal Health (OIE) with the exception of the wildlife reserve, the Kruger National Park (KNP), and adjacent private wildlife parks which are considered as the only endemically infected areas in the country due to the presence of persistently infected African buffaloes, Syncerus caffer. Surrounding the KNP and adjacent parks is a 'buffer zone with vaccination', a narrow strip of farmland immediately adjacent to the KNP where all cattle are regularly vaccinated against FMD and weekly surveillance and strict movement control programmes are in place (Brückner, Vosloo, Kloeck \& Weaver 2003; Thomson, Vosloo \& Bastos 2003). A 'buffer zone where vaccination is not allowed', surrounds the 'buffer zone with vaccination', and separates the endemically infected area from the FMD-free zone. Two of the country's provinces are affected by this control effort, viz. Mpumalanga and Limpopo. As an 
incentive for farmers to present their animals for weekly inspection and disease interventions, the South African government has traditionally provided the means and infrastructure for tick control in communal farming areas such as these. Babesia bovis, the cause of Asiatic babesiosis or redwater, Babesia bigemina, the cause of African babesiosis or redwater and Anaplasma marginale, the cause of gallsickness or anaplasmosis, are all tick-borne parasites of major economic importance in southern Africa (Norval 1994).

Confirmed vectors of $B$. bigemina are Rhipicephalus (Boophilus) decoloratus and Rhipicephalus (Boophilus) microplus (nomenclature according to Horak, Camicas \& Keirans 2002), while B. bovis is transmitted only by the latter tick species. The parasites are widespread in South Africa, except in very low rainfall areas, coinciding with the distribution of their tick vectors; $B$. bigemina being more widespread than $B$. bovis which occurs mainly in high rainfall areas. Young animals commonly harbour a clinically inapparent form of the redwater while acute, nonfatal infections in adult cattle become latent. European cattle breeds are more susceptible to the disease than indigenous breeds but a high mortality rate may occur in Sanga and Zebu breeds (De Vos \& Potgieter 1994). All cattle breeds develop latent infections after recovery from the disease. However, European breeds may retain $B$. bovis infections for life, remaining infective for ticks for up to 2 years while Zebu types lose this infection within 2 years. Babesia bigemina infections rarely persist for more than 1 year in any cattle breed and only remain infective for ticks for 4-7 weeks (De Vos \& Potgieter 1994). Anaplasmosis in cattle is arthropod-borne and caused by Anaplasma marginale, an obligate intra-erythrocytic rickettsia. Haematophagous insects and iatrogenic means may mechanically transmit the parasites and biological transmission is by ixodid ticks.

Rhipicephalus (B.) decoloratus has been considered the most important vector because disease occurrence mainly coincides with the distribution of this tick species. Four other tick species, $R$. (B.) microplus, Rhipicephalus simus, Rhipicephalus evertsi evertsi and Hyalomma marginatum rufipes have been shown to be capable of experimental transmission of anaplasmosis, their distribution overlapping that of $R$. (B.) decoloratus (De Vos \& Potgieter 1994; Potgieter \& Stoltsz 1994). Clinically, anaplasmosis ranges from inapparent infection to severe disease and high mortality, being characterized by fever, progressive anaemia and icterus. Animals that are subclinically infected or that recover from the disease usually remain carriers of the parasite for life (Potgieter \& Stoltsz 1994).

Owing to budgetary constraints and political reforms government subsidization of cattle dipping was suspended in certain provinces, including Limpopo Province, between 1994 and 2002 resulting in farmers having to supply their own acaricides instead of relying on the local Veterinary Services for the provision of free-dipping materials as they had done in the past. By investigating the spatio-temporal patterns of the prevalence of $B$. bovis, B. bigemina and $A$. marginale between 2001 and 2003 in the 'buffer zone with vaccination', this study aimed to determine whether these regional changes in tick control measures had affected the seroprevalence of these three diseases, and to investigate by means of a questionnaire the perceptions of local farmers regarding ticks and tick-borne diseases.

\section{MATERIALS AND METHODS}

\section{Study area}

A longitudinal study was designed to investigate spatio-temporal variation in the seroprevalence of $B$. bovis, $B$. bigemina and $A$. marginale antibodies in cattle in the FMD buffer zone adjoining South Africa's KNP. The park is situated in the north-east part of the country and spans two provinces-Limpopo to the north and Mpumalanga to the south. At the time of the study, the Veterinary Services in Mpumalanga were responsible for providing all dipping materials and maintaining dipping facilities, while in Limpopo, farmers in 'the buffer zone without vaccination' were expected to supply their own acaricides. However, following changes in local departmental policy and availability of funds, farmers in both provinces are at present being supplied with free acaricides.

\section{Recruitment of study population and sample collection}

Twenty-five of the 121 diptanks in the whole buffer zone (the areas with and without FMD vaccination) were selected by stratified random sampling to participate in the study (14 in Limpopo and 11 in Mpumalanga). Participating herd owners were chosen randomly at each diptank, and between 30 and 40 animals of varying ages were randomly selected per owner at each diptank. The original intention was to sample 30 animals older and ten younger than 2 years of age at each diptank. However, this proved impossible to do as the younger age-group was 
either absent from, or poorly represented at the diptanks, resulting in insufficient data to allow for any meaningful comparison between age-groups. Therefore, approximately 40 animals, of any age, were sampled from each diptank. Cattle were sampled once a year between April and August, from 2001 to 2003. Blood was collected in $10 \mathrm{~m} \ell$ sterile, plain vacuum tubes, using a 20-gauge needle from the caudal vein in adult cattle and the jugular in calves while the animals were restrained in a crush. At the laboratory, the tubes were centrifuged, the serum decanted and the sera were frozen and stored for later analysis. Each sampled animal received an ear-tag with a unique identification number. Unfortunately, due to loss of ear-tags, sale of animals, death or absenteeism it was not always possible to sample the same animals each year, particularly by the third year of the study, and new animals had to be recruited from each owner to ensure that 40 animals, or as close to the number as was practical, were sampled.

\section{Questionnaire completion}

Each owner of a sampled herd completed a questionnaire providing data on their herd, dipping practices, their general perception of ticks and tick-borne diseases and the number of animals that had died from a tick-borne disease, giving a total of 72 questionnaires. Only those animals where cause of death was confirmed by blood smear were accepted as having died of a tick-borne disease. Certain questions were only addressed to the Mpumalanga herdsmen on request of the Directorate of Veterinary Services who required the information for a separate study.

\section{Laboratory analyses}

The standard indirect fluorescent antibody test (IFA) as described by Joyner, Donnely, Payner \& Brocklesby (1972) was used to test all blood samples for the presence of antibodies to $B$. bovis and B. bigemina while the Competition Inhibition ELISA for anaplasmosis (Visser, McGuire, Palmer, Davis, Shkap, Pipano \& Knowles 1992; Ndung'u, Aguirre, Rurangirwa, McElwain, McGuire, Knowles \& Palmer 1995) was used to test for antibodies to $A$. marginale.

\section{Statistical analysis}

To account for clustering at the provincial and diptank levels, both serological and questionnaire data were analysed using Stata's survey command series (Intercooled Stata 7.0 for Windows (Stata Cor- poration, College Station, TX)), with province as the stratification variable and diptank (or diptank group) as the cluster (primary sampling unit) variable. Diptanks were grouped according to proximity resulting in seven diptank groups (five in Limpopo and two in Mpumalanga; Fig. 1). Questionnaire data were evaluated using contingency tables to identify significant differences in dipping frequency between provinces and in the number of deaths due to anaplasmosis or babesiosis between provinces. Serological data were analysed using contingency tables to identify significant differences in seroprevalence within years and between provinces. Logistic regression with province, diptank (or diptank group) and year as independent variables, was used to identify risk factors

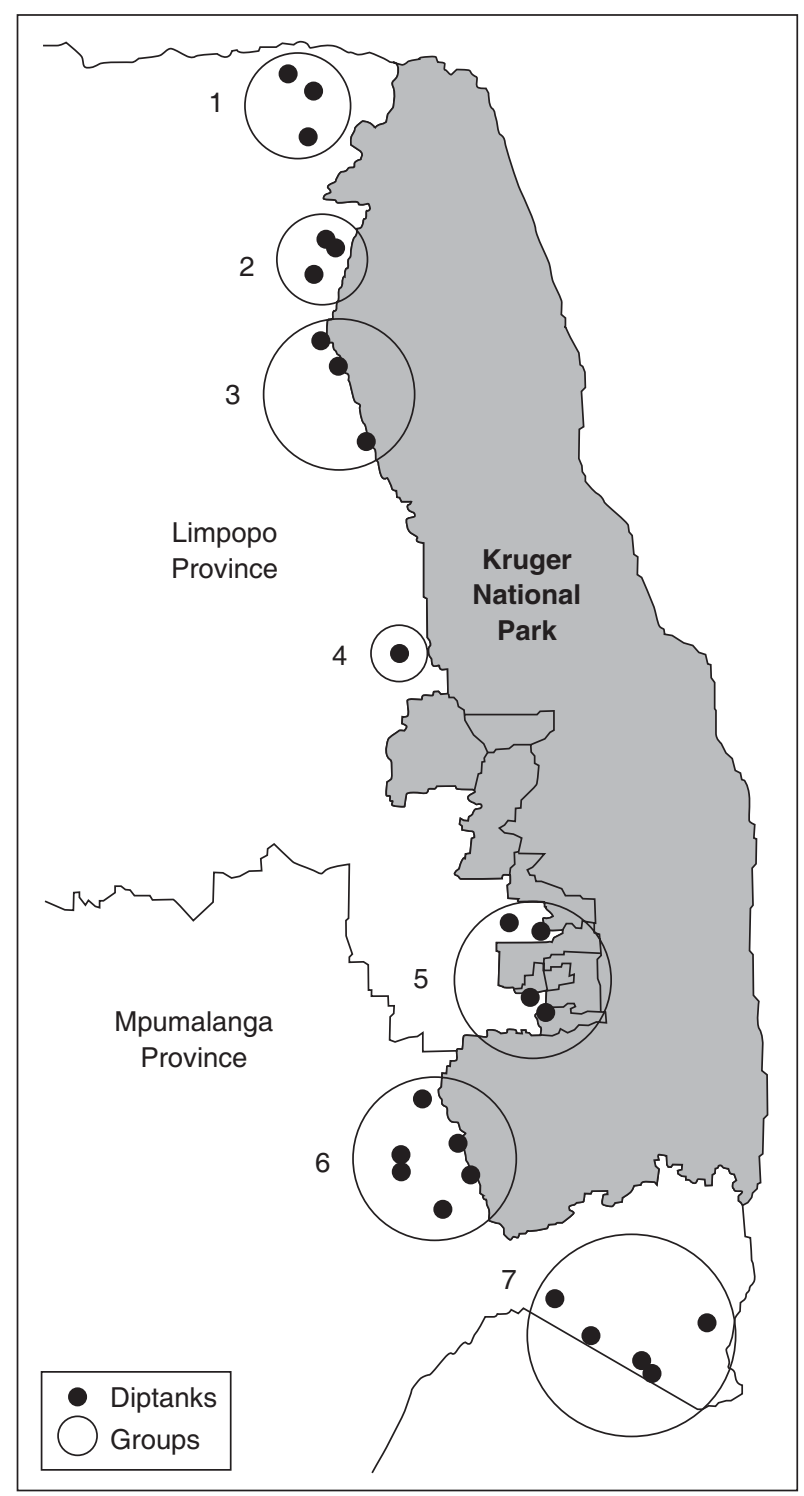

FIG. 1 Location of the 25 diptanks and the seven diptank groups in the foot-and-mouth disease buffer zones surrounding the Kruger National Park 
associated with the prevalence of each disease. Statistical analyses were conducted using SPSS 14.0 for Windows (SPSS Inc., Chicago, IL) and Intercooled Stata 7.0 for Windows (Stata Corporation, College Station, TX). ArcView GIS 3.3 (ESRI, Redlands, CA, USA) was used for spatial data management and presentation.

\section{RESULTS}

\section{Questionnaire study}

Of the 72 herdsmen who completed the questionnaire, the majority owned herds comprised of Nguni crossbreeds (41,57\%), Nguni cattle (14, $19 \%)$, or a mixture of the two $(4,6 \%)$, while five herds $(7 \%)$ comprised Brahmin crossbreeds. Herd size varied from 3 to 198 animals with a mean herd size of 43 animals (SD 42.9). Seven of the 72 herdsmen (10\%) farmed only cattle. All other respondents kept chickens either alone (29 of the herdsmen, $40 \%$ ), or in combination with goats $(24,33.3 \%)$, sheep $(2,3 \%)$ or goats and sheep (12, 17\%).

Sixty-three of the 72 herdsmen (88\%) were aware that they were required by law to dip their cattle. However, all respondents agreed that dipping was good for their animals, although opinions varied as to why it was advantageous with most being of the opinion that it had more than one benefit. Sixty-five $(90 \%)$ felt that it protected against diseases transmitted by ticks, $58(81 \%)$ that it prevented damage to cow's teats, and $54(75 \%)$ that it prevented damage to hides, while $43(60 \%)$ said that the animals looked clean after dipping and $13(18 \%)$ admitted to dipping in order to avoid getting into trouble with the government. Fifty-six of the herdsmen $(78 \%)$ felt that those who failed to bring their cattle for regular dipping should be fined.

There was a significant difference between provinces in summer dipping frequency $(\mathrm{Chi}=4.3$, df $=$ $1, P=0.04$ ) with just over $80 \%$ of Mpumalanga farmers dipping once a week in summer, although this figure rose to almost $100 \%$ in Limpopo Province (Table 1). Sixty-four (89\%) of the farmers said they dipped all their cattle, while one $(1 \%)$ admitted to dipping only part of his herd. However, $65(88 \%)$ of the respondents felt that their animals would get sick if not dipped, yet only $53(82 \%)$ of these said that if for some reason the diptank was closed they would buy acaricide in order to treat their animals. The remainder were content to wait until the diptank reopened, even if this took a few months.

Mpumalanga and Limpopo herdsmen appeared equally aware of alternative methods of tick control. The most well-known alternative form of treatment was hand-spraying $(48,67 \%)$, followed by pour-on remedies $(32,44 \%)$, spray-races $(12,17 \%)$, handdeticking $(10,14 \%)$, used motor oil $(5,7 \%)$, disinfectant $(1,1 \%)$ and traditional medication (1, $1 \%)$. Twenty-three $(32 \%)$ of the herdsmen questioned preferred one or more of these alternative methods of tick control to dipping due to ease of administration $(10,43 \%)$, efficacy $(5,22 \%)$ or cost $(3,13 \%)$. General consensus as to how long it would take an animal to get sick after being bitten by a tick varied. A quarter of respondents (18 people) thought that it would take less than 15 days, 14 (19\%) did not know, $11(15 \%)$ felt it would take between 16 and 28 days, $9(13 \%)$ that it would take $1-2$ months, and $2(3 \%)$ thought it would take more than 2 months.

Mpumalanga herdsmen were asked whether it was the presence of ticks on an animal that caused it to become sick or whether it was due to diseases carried by the ticks. Four (11\%) felt that it was the presence of the tick while eight (23\%) answered that it was due to diseases carried by the parasites. However, $17(49 \%)$ felt that it was due to a combination of the two, and two $(6 \%)$ did not know. Twelve of the Mpumalanga herdsmen (34\%) agreed that only one tick was necessary to make an animal sick, while the rest either did not know $(8,23 \%)$ or felt that it required a number of ticks, although the actual amount varied. Five (14\%) thought $2-5$ ticks were needed, four (11\%) thought that $6-15$ were necessary, while one $(3 \%)$ herdsman thought it required 16-30 parasites and another (3\%), that it required more than 30 .

TABLE 1 Dipping frequency of 72 cattle herds in summer and winter in the foot-and-mouth disease buffer zones in Mpumalanga and Limpopo Provinces

\begin{tabular}{|l|l|l|l|l|}
\hline \multirow{2}{*}{ Season } & \multicolumn{2}{l|}{ Limpopo Province } & \multicolumn{2}{l|}{ Mpumalanga Province } \\
\cline { 2 - 5 } & Weekly $(\boldsymbol{n}[\%])$ & Fortnightly $(\boldsymbol{n}[\%])$ & Weekly $(\boldsymbol{n}[\%])$ & Fortnightly $(\boldsymbol{n}[\%])$ \\
\hline Summer & $35(97)$ & $1(3)$ & $28(82)$ & $6(18)$ \\
Winter & $26(72)$ & $10(28)$ & $27(79)$ & $7(21)$ \\
\hline
\end{tabular}


Only nine (26\%) of the Mpumalanga herdsmen felt that they were solely responsible for the health of their cattle. Five (14\%) thought the government was responsible while $17(49 \%)$ felt the responsibility fell jointly on them and the government. At the time of the study dipping was free of charge in Mpumalanga. The herdsmen were therefore asked what they would do if required to pay R0.50 (approximately US $\$ 0.08$ ) per animal to cover the cost of each dipping. Only $12(34 \%)$ said that they would pay the R0.50 and continue to bring all their animals, five (14\%) responded that they would stop bringing their animals, four $(11 \%)$ would dip only if their cattle had ticks, two $(6 \%)$ said they would only bring some cattle for dipping and one person (3\%) said they would dip their cattle less frequently.

Thirty-two (91\%) of the Mpumalanga herdsmen were satisfied with the current dipping system, yet only $18(49 \%)$ of the Limpopo herdsmen felt the same way, citing poor efficacy of the dipping chemical (11, $61 \%)$, lack of dipping chemical $(4,22 \%)$ and inability to afford their own acaricide $(4,22 \%)$ as reasons for dissatisfaction. There was no significant difference in the number of herds that experienced deaths due to either babesiosis (six herds) or anaplasmosis (seven herds) at the province level.

\section{Seroprevalence study}

Serology data was analysed at both the provincial and diptank group level. There was no significant difference in seroprevalence of $B$. bovis between the two provinces for any of the 3 years. In Mpumalanga, the proportion of animals testing seropositive for $B$. bovis decreased slightly over the 3 years (51.4-48.1\%), but increased in Limpopo from 44.2 to $59.7 \%$ (Table 2). There was a significant difference in the seroprevalence of $B$. bigemina between the two provinces in 2003; $33.1 \%$ of animals tested positive in Limpopo while only $17.1 \%$ tested positive in Mpumalanga (Chi $=28.8, \mathrm{df}=1, P=0.01$; Table 2). In Mpumalanga, seroprevalence of $B$. bigemina halved during the study period (35.6-17.6\%) and decreased in Limpopo from 46.6 to $33.1 \%$ (Table 2). There was a significant difference in seroprevalence of $A$. marginale between the two provinces in $2001 ; 75.1 \%$ of animals tested positive in Mpumalanga while $58.6 \%$ tested positive in Limpopo (Chi $=26.9$, df =1, $P=0.05$; Table 2). In Mpumalanga, mean seroprevalence of $A$. marginale fluctuated but was over $75 \%$ for 2 of the 3 years, while in Limpopo the proportion of seropositive animals increased during the trial period from 58.6 to $78.4 \%$ (Table 2).

The proportion of animals seropositive for $B$. bovis differed significantly between diptank groups for each of the 3 years, although no diptank group exhibited a consistently high or low seroprevalence during the study period (Table 3). Between 2001 and 2003, the proportion of animals seropositive to $B$. bovis decreased slightly in four of the diptank groups. The proportion of animals seropositive for $B$. bigemina also differed significantly between diptank groups for each of the 3 years, with Diptank Groups 5 and 6 displaying consistently low seroprevalences for the disease (Table 3). Between 2001 and 2003 the proportion of animals testing positive for $B$. bigemina

TABLE 2 Seroprevalence of Babesia bovis, Babesia bigemina and Aanaplasma marginale in cattle in the foot-and-mouth disease buffer zones in Mpumalanga and Limpopo Provinces between 2001 and 2003

\begin{tabular}{|c|c|c|c|c|c|}
\hline \multirow{2}{*}{ Province } & \multirow{2}{*}{ Year } & \multirow{2}{*}{$\begin{array}{l}\text { Cattle sampled } \\
(n)\end{array}$} & \multicolumn{3}{|c|}{ Seropositive cattle $(\boldsymbol{n}[\%, 95 \% \mathrm{Cl}])$} \\
\hline & & & B. bovis & B. bigemina & A. marginale \\
\hline \multirow{3}{*}{ Mpumalanga } & 2001 & 385 & $\begin{array}{l}198(51.4 \\
46.3-56.5)\end{array}$ & $\begin{array}{l}137(35.6 \\
30.8-40.6)\end{array}$ & $\begin{array}{l}289(75.1 \\
70.4-79.3)\end{array}$ \\
\hline & 2002 & 397 & $\begin{array}{l}199(50.1, \\
45.1-55.2)\end{array}$ & $\begin{array}{l}145(36.6 \\
31.8-41.5)\end{array}$ & $\begin{array}{l}230(57.9 \\
52.9-62.8)\end{array}$ \\
\hline & 2003 & 432 & $\begin{array}{l}208(48.1 \\
43.3-53.0)\end{array}$ & $\begin{array}{l}76(17.6 \\
14.1-21.5)\end{array}$ & $\begin{array}{l}354 \text { (81.9, } \\
78.0-85.5)\end{array}$ \\
\hline \multirow{3}{*}{ Limpopo } & 2001 & 536 & $\begin{array}{l}237(44.2 \\
40.0-48.5)\end{array}$ & $\begin{array}{l}250(46.6 \\
42.4-51.0)\end{array}$ & $\begin{array}{l}314(58.6 \\
54.3-62.8)\end{array}$ \\
\hline & 2002 & 490 & $\begin{array}{l}247 \text { (50.4, } \\
45.9-54.9)\end{array}$ & $\begin{array}{l}154(31.4, \\
27.3-35.7)\end{array}$ & $\begin{array}{l}345(70.4 \\
66.2-74.4)\end{array}$ \\
\hline & 2003 & 486 & $\begin{array}{l}290(59.7, \\
55.2-64.1)\end{array}$ & $\begin{array}{l}161(33.1 \\
29.0-37.5)\end{array}$ & $\begin{array}{l}381(78.4 \\
74.5-82.0)\end{array}$ \\
\hline
\end{tabular}


TABLE 3 Seroprevalence of Babesia. bovis, Babesia. bigemina and Anaplasma marginale between 2001 and 2003 for the seven diptank groups in the foot-and-mouth disease buffer zones in Mpumalanga and Limpopo Provinces

\begin{tabular}{|c|c|c|c|c|c|c|c|c|c|c|}
\hline \multirow{3}{*}{ Province } & \multirow{3}{*}{$\begin{array}{l}\text { Diptank } \\
\text { group }\end{array}$} & \multicolumn{9}{|c|}{ Seropositive cattle $[n(\%, 95 \%$ Cl)] } \\
\hline & & \multicolumn{3}{|l|}{ B. bovis } & \multicolumn{3}{|c|}{ B. bigemina } & \multicolumn{3}{|c|}{ A. marginale } \\
\hline & & 2001 & 2002 & 2003 & 2001 & 2002 & 2003 & 2001 & 2002 & 2003 \\
\hline \multirow[t]{5}{*}{$\begin{array}{l}\text { Limpopo } \\
\text { Province }\end{array}$} & 1 & $\begin{array}{l}48(40.0 \\
31.1-49.3)\end{array}$ & $\begin{array}{l}14(21.9 \\
12.5-34.0)\end{array}$ & $\begin{array}{l}27(36.0 \\
25.2-47.9)\end{array}$ & $\begin{array}{l}53(44.2 \\
35.1-53.5)\end{array}$ & $\begin{array}{l}28(43.8 \\
31.4-56.7)\end{array}$ & $\begin{array}{l}26(34.7 \\
24.0-46.5)\end{array}$ & $\begin{array}{l}52(43.3 \\
34.3-52.7)\end{array}$ & $\begin{array}{l}23(35.9, \\
24.3-48.9)\end{array}$ & $\begin{array}{l}42(56.0 \\
44.1-67.5)\end{array}$ \\
\hline & 2 & $\begin{array}{l}92(80.7 \\
72.2-87.5)\end{array}$ & $\begin{array}{l}84(69.4 \\
60.4-77.5)\end{array}$ & $\begin{array}{l}89 \text { (74.2, } \\
65.4-81.7)\end{array}$ & $\begin{array}{l}74(64.9, \\
55.4-73.6)\end{array}$ & $\begin{array}{l}38(31.4, \\
23.3-40.5)\end{array}$ & $\begin{array}{l}43(35.8 \\
27.3-45.1)\end{array}$ & $\begin{array}{l}79 \text { (69.3, } \\
59.9-77.6)\end{array}$ & $\begin{array}{l}86 \text { (71.1, } \\
62.1-79.0)\end{array}$ & $\begin{array}{l}102(85.0 \\
77.3-90.0)\end{array}$ \\
\hline & 3 & $\begin{array}{l}79 \text { (69.9, } \\
60.6-78.2)\end{array}$ & $\begin{array}{l}73(64.0 \\
54.5-72.8)\end{array}$ & $\begin{array}{l}83(68.0 \\
59.0-76.1)\end{array}$ & $\begin{array}{l}80 \text { (70.8, } \\
61.5-79.0)\end{array}$ & $\begin{array}{l}50(43.9, \\
34.6-53.5)\end{array}$ & $\begin{array}{l}51 \text { (41.8, } \\
32.9-51.1)\end{array}$ & $\begin{array}{l}72(63.7 \\
54.1-72.6) \\
\end{array}$ & $\begin{array}{l}73(64.0, \\
54.5-72.8)\end{array}$ & $\begin{array}{l}96 \text { (78.7, } \\
70.4-85.6)\end{array}$ \\
\hline & 4 & $\begin{array}{l}2(5.7, \\
0.7-19.2)\end{array}$ & $\begin{array}{l}36 \text { (85.7, } \\
71.5-94.6)\end{array}$ & $\begin{array}{l}24(58.5, \\
42.1-73.7)\end{array}$ & $\begin{array}{l}17(48.6 \\
31.4-66.0)\end{array}$ & $\begin{array}{l}15(35.7 \\
21.5-52.0)\end{array}$ & $\begin{array}{l}22(53.7, \\
37.4-69.3)\end{array}$ & $\begin{array}{l}21(60.0 \\
42.1-76.1)\end{array}$ & $\begin{array}{l}32(76.2 \\
60.5-87.9)\end{array}$ & $\begin{array}{l}40(97.6 \\
87.1-100.0)\end{array}$ \\
\hline & 5 & $\begin{array}{l}16(10.4 \\
6.1-16.3)\end{array}$ & $\begin{array}{l}40(26.8 \\
19.9-34.7)\end{array}$ & $\begin{array}{l}67(52.3 \\
43.4-61.2)\end{array}$ & $\begin{array}{l}26(16.9 \\
11.3-23.8)\end{array}$ & $\begin{array}{l}23(15.4 \\
10.0-22.3)\end{array}$ & $\begin{array}{l}19(14.8 \\
9.2-22.2)\end{array}$ & $\begin{array}{l}90(58.4 \\
50.2-66.3)\end{array}$ & $\begin{array}{l}131(87.9 \\
81.6-92.7)\end{array}$ & $\begin{array}{l}101 \text { (78.9, } \\
70.8-85.6)\end{array}$ \\
\hline \multirow[t]{2}{*}{$\begin{array}{l}\text { Mpumalanga } \\
\text { Province }\end{array}$} & 6 & $\begin{array}{l}105(55.6 \\
48.2-62.8)\end{array}$ & $\begin{array}{l}104(50.2 \\
43.2-57.2)\end{array}$ & $\begin{array}{l}95(39.4, \\
33.2-45.9)\end{array}$ & $\begin{array}{l}63(33.3 \\
26.7-40.5)\end{array}$ & $\begin{array}{l}50(24.2 \\
18.5-30.6)\end{array}$ & $\begin{array}{l}(36(14.9, \\
10.7-20.1)\end{array}$ & $\begin{array}{l}144(76.2 \\
69.5-82.1)\end{array}$ & $\begin{array}{l}128(61.8 \\
54.8-68.5)\end{array}$ & $\begin{array}{l}206(85.5 \\
80.4-89.7)\end{array}$ \\
\hline & 7 & $\begin{array}{l}93(47.4, \\
40.3-54.7)\end{array}$ & $\begin{array}{l}95(50.0 \\
42.7-57.3)\end{array}$ & $\begin{array}{l}113(59.2 \\
51.8-66.2)\end{array}$ & $\begin{array}{l}74(37.8 \\
30.9-44.9)\end{array}$ & $\begin{array}{l}95(50.0, \\
42.7-57.3)\end{array}$ & $\begin{array}{l}40(20.9 \\
15.4-27.4)\end{array}$ & $\begin{array}{l}145(74.0 \\
67.2-79.9)\end{array}$ & $\begin{array}{l}102(53.7 \\
46.3-60.9)\end{array}$ & $\begin{array}{l}148 \text { (77.5, } \\
70.9-83.2)\end{array}$ \\
\hline \multirow{2}{*}{\multicolumn{2}{|c|}{$\begin{array}{l}P \text {-value } \\
\chi^{2} \text { (df 6) }\end{array}$}} & $<0.001$ & $<0.001$ & 0.04 & $<0.001$ & $<0.001$ & $<0.001$ & 0.09 & $<0.001$ & 0.14 \\
\hline & & 190.4 & 100.85 & 62.3 & 111.0 & 61.51 & 67.5 & 46.6 & 73.9 & 42.4 \\
\hline
\end{tabular}


TABLE 4 Final logistic regression model for factors associated with the seroprevalence of Babesia bovis, Babesia bigemina and Anaplasma marginale in cattle in the foot-and-mouth disease buffer zones in Mpumalanga and Limpopo Provinces (year, province and diptank group included as independent variables)

\begin{tabular}{|l|l|c|c|l|c|}
\hline Disease & Risk factor & B & Std error & $\boldsymbol{P}$-value & $95 \%$ Cl \\
\hline \multirow{3}{*}{ B. bovis } & Year & 0.146 & 0.13 & 0.278 & -0.13 to 0.42 \\
& Province & 0.627 & 0.53 & 0.246 & -0.46 to 1.72 \\
& Diptank group & -0.203 & 0.16 & 0.207 & -0.53 to 0.12 \\
& Constant & -291.67 & 262.67 & 0.278 & -835.0 to 251.69 \\
\hline \multirow{3}{*}{ B. bigemina } & Year & -0.362 & 0.10 & 0.001 & -0.57 to 0.15 \\
& Province & 0.447 & 0.43 & 0.314 & -0.45 to -1.343 \\
& Diptank group & -0.226 & 0.09 & 0.018 & -0.41 to -0.04 \\
& Constant & 723.98 & 200.71 & 0.001 & 308.79 to 1139.18 \\
\hline \multirow{2}{*}{ A. marginale } & Year & 0.350 & 0.11 & 0.006 & 0.11 to 0.59 \\
& Province & -0.541 & 0.33 & 0.119 & -1.23 to 0.15 \\
& Diptank group & 0.191 & 0.11 & 0.088 & -0.03 to 0.42 \\
& Constant & -700.11 & 229.65 & 0.006 & -1175.18 to -225.04 \\
\hline
\end{tabular}

decreased in six of the seven diptank groups. The proportion of animals seropositive for $A$. marginale only differed significantly between diptank groups in 2002. The number of diptank groups where more than $70 \%$ of the animals tested positive for $A$. marginale increased over the 3 years from two to six. Diptank Group 1 consistently recorded the lowest $A$. marginale seroprevalence.

Logistic regression revealed that none of the risk factors, year, province, diptank (or diptank group), were significantly associated with the prevalence of $B$. bovis. However, year was significantly associated with both $A$. marginale $(P=0.006)$ and $B$. bigemina $(P=0.001)$, while diptank group was a significant risk factor for $B$. bigemina $(P=0.018)$ (Table 4$)$.

\section{DISCUSSION}

Anaplasma marginale was the most prevalent of the three potentially disease-causing blood parasites studied and the number of animals testing positive for it increased in both provinces between 2001 and 2003, although this increase was almost three times greater in Limpopo than in Mpumalanga (19.8 versus $6.8 \%$, respectively). Between 2001 and 2003 the seroprevalence of $B$. bovis decreased very slightly in Mpumalanga from 51.4 to $48.1 \%$ but increased in Limpopo from 44.2 to $59.7 \%$. Babesia bigemina was the least prevalent of the three parasites in both provinces and was the only one for which the proportion of seropositive animals decreased markedly over the 3 years, achieving a mean seroprevalence of $17.6 \%$ in Mpumalanga by 2003 and $33.1 \%$ in Limpopo. Although seroprevalence of $A$. marginale and $B$. bovis increased in both provinces during the study period, the greater increase observed in Limpopo, where farmers were expected to supply their own acaricides, suggests that this was due to the removal of government-subsidised dipping, although the antibody seroprevalence of Anaplasma may have been additionally influenced by increased mechanical transmission by biting flies.

Of the 72 farmers who completed the questionnaire, 71 claimed to dip all cattle every week in summer. However, as replies to the questionnaire revealed local knowledge of ticks and tick-borne diseases to be highly variable and sometimes incorrect, farmers might not have been fully aware of the need for regular dipping and therefore, once expected to provide their own acaricides, might not have been dipping as often as they said they were. It is interesting to note that over $60 \%$ of the questionnaire respondents felt that either the government was responsible for the health of their cattle, or that they and the government were jointly responsible. Although this question was only addressed to the Mpumalanga herdsmen, it is likely that the farmers in Limpopo were of the same opinion. Thus, if the herdsmen felt that it was the province's duty to provide free acaricides, they may have resisted supplying their own. Although the Veterinary Service in Limpopo has re- 
sumed responsibility for the provision of dipping ma terials, it is doubtful whether this on its own will be sufficient to decrease the seroprevalence of $B$. bo$v i s$ and $A$. marginale in the region. The questionnaire responses identified a very real need to educate the local farmers on the importance of ticks and tick-borne diseases before the success of any dipping policy, whether government subsidized or otherwise, is guaranteed.

Of the three parasites studied, $B$. bigemina was the only one to show a marked decrease in seroprevalence between 2001 and 2003. It is not possible to attribute this to good tick control strategies and, in contrast the increased seroprevalence of $B$. bovis and $A$. marginale to poor tick control strategies, as the tick burden would be the same for all three diseases. Rhipicephalus (B.) microplus is the sole vector of $B$. bovis in South Africa, whereas B. bigemina can be spread by both $R$. (B.) microplus and $R$. (B.) decoloratus (De Vos \& Potgieter 1994). Furthermore, Tønnesen, Penzhorn, Bryson, Stoltsz \& Masibigiri (2004) found that when $R$. (B.) microplus and $R$. (B.) decoloratus occurred in the same region, $R$. (B.) microplus tended to displace $R$. (B.) decoloratus over time and that this displacement was rapid and complete at communal diptanks. Thus, the overall decrease in seroprevalence of $B$. bigemina might indicate a gradual displacement of $R$. (B.) decoloratus by $R$. (B.) microplus in the region and, in fact, a recent study in Limpopo found $R$. (B.) microplus to be more plentiful than $R$. (B.) decoloratus at the four communal grazing areas investigated (Rikhotso, Stoltsz, Bryson \& Sommerville 2005). Future research into the temporal abundance and distribution of $R$. (B.) microplus and $R$. (B.) decoloratus in the region would provide an indication as to whether one vector is in fact displacing the other, or if the contrasting trends in seroprevalence of $B$. bovis and $B$. bigemina can be attributed to some other cause.

Based on a study of bovine babesiosis in Zimbabwe, Norval, Fivaz, Lawrence \& Daillecourt (1983) defined the following five epidemiological situations on the basis of the frequency of occurrence of serological positives and disease history:

(i) Enzootically (endemically) stable situations (81$100 \%$ positive sera)

(ii) Situations approaching endemic stability (61$80 \%$ positive sera)

(iii) Endemically unstable situations (21-60\% positive sera)

(iv) Minimal disease situation (1-10\% positive sera)

(v) Disease-free situations ( $0 \%$ positive sera).
They further indicated that clinical babesiosis was most possible at localities where the percentage of serological positives for either $B$. bovis or $B$. bigemina was in the range of $21-60 \%$, while the disease was not a cause of significant cattle mortality at localities where no Babesia antibodies were detected or where the percentage of serological positives was over $80 \%$. In the current study, despite the implementation of what could be considered an intensive dipping strategy in both provinces (Table 1), which should ostensibly minimize tick infestation and thus Babesia infection challenge, a minimal disease situation was only found for $B$. bigemina in Mpumalanga during 2003 (Table 2). The remainder displayed an endemically unstable situation. As regards the seven diptank groups during 2003 (Table 3), only Diptank Groups 5 (Limpopo) and 6 (Mpumalanga), established a minimal disease situation for $B$. bigemina. Diptank Groups 2 and 3 (Limpopo) were in a situation approaching endemic stability for $B$. bovis, while all other groups were endemically unstable for both $\mathrm{Ba}$ besia species, the latter situation being indicative of high risk of clinical disease (Norval et al. 1983) and a probable cause for concern should dipping be disrupted in any way.

\section{CONCLUSION}

Seroprevalence of $A$. marginale and $B$. bovis increased during the study period and for both parasites this increase was greater in Limpopo where farmers had to supply their own acaricide than in Mpumalanga where dipping materials were provided by the local provincial Veterinary Services, suggesting that regional differences in dipping policy may have affected the seroprevalence of these two diseases. Conversely, the number of animals testing positive for $B$. bigemina decreased during the study period, particularly in Mpumalanga. The contradictory behaviour of this parasite may be the result of vector displacement rather than more effective tick control measures. Responses to a questionnaire on ticks and tick-borne diseases revealed local knowledge on the subject to be highly variable and sometimes incorrect.

\section{ACKNOWLEDGEMENTS}

We thank Brenda Botha and Heloise Heyne for their considerable assistance with the collection of samples in the field, as well as the many officers of the provincial Veterinary Services involved, especially the animal health inspectors at the various diptanks. 


\section{REFERENCES}

BRÜCKNER, G.K., VOSLOO, W., KLOECK, P.E.L.G. \& WEAVER, D.B. 2003. Eradication of foot-and-mouth disease by using stamping-out and vaccination: the examples of the outbreaks due to serotype O and SAT-1 in South Africa in Foot-and-mouth disease: control strategies, edited by B. Dodet \& M. Vicari. Symposium Proceedings, Lyon, France 2-5 June 2002: 135-143.

DE VOS, A.J. \& POTGIETER, F.T. 1994. Bovine babesiosis, in Infectious diseases of livestock with special reference to southern Africa, edited by J.A.W. Coetzer, G.R. Thomson \& R.C. Tustin. Cape Town: Oxford University Press.

HORAK, I.G., CAMICAS, J.-L. \& KEIRANS, J.E. 2002. The Ixodidae, Amblyommidae and Nuttalliellidae (Acari: Ixodida): a world list of valid tick names. Experimental and Applied Acarology, 28:7-54.

JOYNER, L.P., DONNELY, J., PAYNER, R. \& BROCKLESBY, D.W. 1972. The indirect fluorescent antibody test for the differentiation of infections with Babesia divergens or Babesia major. Research in Veterinary Science, 13:515-518.

NDUNG'U, L.W., AGUIRRE, C., RURANGIRWA, F.R., McELWAIN, T.F., McGUIRE, T.C., KNOWLES, D.P. \& PALMER, G.H. 1995. Detection of Anaplasma ovis infection in goats by major surface protein 5 competitive inhibition enzyme-linked immunosorbent assay. Journal of Clinical Microbiology, 33: 675-679.

NORVAL, R.A.I. 1994. Vectors: Ticks, in Infectious diseases of livestock with special reference to southern Africa, edited by J.A.W. Coetzer, G.R. Thomson \& R.C. Tustin. Cape Town: Oxford University Press.
NORVAL, R.A.I., FIVAZ, B.H., LAWRENCE, J.A. \& DAILLECOURT, T. 1983. Epidemiology of tick-borne diseases of cattle in Zimbabwe. I. Babesiosis. Tropial Animal Health and Production, 15:87-94.

POTGIETER, F.T. \& STOLTSZ, W.H. 1994. Bovine anaplasmosis, in Infectious diseases of livestock with special reference to southern Africa, edited by J.A.W. Coetzer, G.R. Thomson \& R.C. Tustin. Cape Town: Oxford University Press.

RIKHOTSO, B.O., STOLTSZ, W.H., BRYSON, N.R. \& SOMMERVILLE, J.E. 2005. The impact of 2 dipping systems on endemic stability to bovine babesiosis and anaplasmosis in cattle in 4 communally grazed areas in Limpopo Province, South Africa. Journal of the South African Veterinary Association, 76:217-223.

THOMSON, G.R., VOSLOO, W. \& BASTOS, A.D.S. 2003. The epidemiology and control of foot-and-mouth disease in subSaharan Africa Foot-and-mouth disease: control strategies, edited by B. Dodet \& M. Vicari. Symposium Proceedings, Lyon, France, 2-5 June 2002: 125-134.

TØNNESEN, M.H., PENZHORN, B.L., BRYSON, N.R., STOLTSZ, W.H. \& MASIBIGIRI, T. 2004. Displacement of Boophilus decoloratus by Boophilus microplus in the Soutpansberg region, Limpopo Province, South Africa. Experimental and Applied Acarology, 32:199-208.

VISSER, E.S., McGUIRE, T.C., PALMER, G.H., DAVIS, W.C., SHKAP, V., PIPANO, E. \& KNOWLES, D.P. Jr. 1992. The Anaplasma marginale msp5 gene encodes a 19 Kilodalton protein conserved in all recognized Anaplasma species. Infection and Immunity, 60:5139-5144. 